\title{
MDA FINANCIAL DISTRESS PREDICTION MODEL FOR SELECTED BALKAN COUNTRIES
}

\author{
Marek Durica ${ }^{18}$ \\ Peter Adamko ${ }^{19}$ \\ Katarina Valaskova ${ }^{20}$
}

Received: April 12, 2018 / Revised: May 19, 2018 / Accepted: June 29, 2018

(C) Association of Economists and Managers of the Balkans

\begin{abstract}
The issue of company financial distress and the early prediction of potential bankruptcy is one of the most discussed issues of economists around the world in recent decades. The most widely used method to create these models is Multidimensional Discrimination Analysis from the first attempts in the 1960s to the present. In the paper we present prediction model for some emerging market countries in Balkan region created using a Multidimensional Discriminant Analysis method based on real data from the financial statements obtained from Amadeus - A database of comparable financial information for public and private companies across Europe. Our database contains data more than 200000 companies and about 25 predictors. Using this model, it is possible to predict the financial difficulties of companies one year in advance.
\end{abstract}

Keywords: Prediction model, Financial distress, Multidimensional Discrimination Analysis, Prediction ability.

JEL Classifications C52 $\cdot$ C53 $\cdot$ G33

This paper was presented at the Second International Scientific Conference on Economics and Management - EMAN 2018, March 22 2018, Ljubljana, Slovenia, www.eman-conference.org

$\square$ Marek Durica

marek.durica@fpedas.uniza.sk

18 University of Zilina, Faculty of Operation and Economics of Transport and Communications, Zilina, Slovak Republic

19 University of Zilina, Faculty of Operation and Economics of Transport and Communications, Zilina, Slovak Republic

20 University of Zilina, Faculty of Operation and Economics of Transport and Communications, Zilina, Slovak Republic 


\section{INTRODUCTION}

Bankruptcy of the company brings huge economic losses for the investors and other stakeholders. Its existence calls for an analysis of the bankruptcy causes and early identification of signs of approaching bankruptcy. These signs can be reflected in the company financial statements. For this reason, accounting data are a common source of information for assessing the financial situation of an enterprise (Siekelova et al, 2017).

Many authors are trying to create a model for early identification and prevention of financial distress or bankruptcy. Such model is significant contribution to the efficiency of company management. In this area, papers by Altman and Ohlson can be considered as groundbreaking (Kliestikova, Misankova and Kliestik, 2017). Altman (1968) created the first commonly used bankruptcy model using a Multidimensional Discrimination Analysis (MDA). According to many authors, Altman's model still represents an effective tool to predict bankruptcy (Li, Ragozar, 2012). Another commonly used technique for creation of prediction models is logistic regression (logit) models. In 1980, this technique of prediction model creation was used for the first time by Ohlson (1980).

Currently, there exists many prediction models developed at a particular time and in conditions of particular economies. Many of them have been created for companies in a particular sector of national economy. For example, in New Zealand Chung, Tan and Holdsworth (2008) have created classification model for companies in the field of finance industry. Sun and Li (2012) have applied the Logit method and also MDA method for creation of company distress prediction model in China. In Iran, Shams, Sheikhi and Sheikhi (2011) have developed a Logit bankruptcy prediction model. Bellovary, Giacomino and Akers (2007) have described the situation about existing models for predicting bankruptcy from 1930 to 2007. In 2017, Altman et al. (2016) use the original ZScore model developed by Altman in 1983 for non-financial companies across all industrial sectors, from 31 European and three non-European countries using different modifications of the original model.

Of course, even authors in the western part of the Balkan region are concerned with the issue of bankruptcy prediction models. For example, Jovanovic, Todorovic, Grbic (2017) and Simic, Kovacevic, Simic (2012), but also Obradovic et al. (2018) have created prediction models for Serbian companies. The topic of identifying financial problems is also discussed for Croatian companies (Kundid, Ercegovac; 2011; Sarlija, Jeger, 2011; Pervan, Pavic, Pervan, 2014; Zikovic, 2018). Further, for Slovene companies several prediction models have been created (Bonca, Ponikvar, Pusnik and Tajnikar, 2015; Zidek, 2016).

\section{SAMPLE AND METHODOLOGY}

Our database contains data more than 200000 companies from Croatia, Serbia, Slovenia, Macedonia and Montenegro. Table 1 lists the frequencies of these companies according to these countries. The most numerous is the group of Croatian companies and, on the other hand, the least of Montenegrin. 
Table 1: Company frequencies

\begin{tabular}{|l|r|r|}
\hline Country & Frequency & Percent \\
\hline Croatia & 64076 & 31,5 \\
\hline Macedonia & 44973 & 22,1 \\
\hline Montenegro & 6730 & 3,3 \\
\hline Serbia & 42017 & 20,6 \\
\hline Slovenia & 45804 & 22,5 \\
\hline Total & 203600 & 100,0 \\
\hline
\end{tabular}

Real data in our database was calculated from the financial statements obtained from Amadeus A database of comparable financial information for public and private companies across Europe. Table 2 lists potential predictors and the methods of their calculation. Two of these predictors are indicators: country-specificity and size of the companies (Small, Medium and Large)). These indicators have to be encoded as dummy variables. The remaining predictors are financial ratios calculated from financial statements from the year 2015 .

Table 2: List of predictors

\begin{tabular}{|c|l|}
\hline Predictor & Formula \\
\hline X01 & Sales/Total Assets \\
\hline X02 & Current Assets/Current Liabilities \\
\hline X04 & Net Income/Shareholders Equity \\
\hline X07 & Net income/Total Assets \\
\hline X08 & Working Capital/Total Assets \\
\hline X09 & EBIT/Total Assets \\
\hline X10 & Liabilities/Total Assets \\
\hline X11 & Current Assets/Total Assets \\
\hline X12 & Cash \& Cash Equivalents/Total Assets \\
\hline X15 & Current Liabilities/Total Assets \\
\hline X16 & Current Assets/Sales \\
\hline X18 & Stock/Sales \\
\hline X20 & Net Income/Sales \\
\hline X21 & Non-current Liabilities/Total Assets \\
\hline X22 & Cash \& Cash Equivalents/Current Liabilities \\
\hline X24 & Working Capital/Sales \\
\hline X25 & Current Ratio \\
\hline X26 & (Current Assets-Stock)/Current Liabilities \\
\hline X27 & ROA \\
\hline X28 & ROE \\
\hline X30 & Solvency Ratio \\
\hline X35 & Profit Margin \\
\hline X36 & Net Current Assets \\
\hline X37 & Working Capital \\
\hline Country & Croatia, Macedonia, Montenegro, Serbia or Slovenia \\
\hline Size & Small, Medium or Large \\
\hline
\end{tabular}

Our aim is to create a model predicting the company's financial distress one year in advance. Therefore, the output variable Distress identifies the financial distress of the companies in 2016. Table 3 describes the frequencies and percentages of companies in selected countries. 
Table 3: Frequencies of companies

\begin{tabular}{|l|r|r|r|}
\hline Country & Distress & Frequency & Percent \\
\hline \multirow{3}{*}{ Croatia } & No & 46103 & 72,0 \\
\hline \multirow{3}{*}{ Macedonia } & Yes & 17973 & 28,0 \\
\cline { 2 - 4 } & Total & 64076 & 100,0 \\
\cline { 2 - 4 } & No & 36317 & 80,8 \\
\cline { 2 - 4 } & Yes & 8656 & 19,2 \\
\cline { 2 - 4 } & Total & 44973 & 100,0 \\
\cline { 2 - 4 } & No & 3987 & 59,2 \\
\cline { 2 - 4 } & Yes & 2743 & 40,8 \\
\cline { 2 - 4 } & Total & 6730 & 100,0 \\
\cline { 2 - 4 } & No & 31754 & 75,6 \\
\hline \multirow{3}{*}{ Slovenia } & Yes & 10263 & 24,4 \\
\cline { 2 - 4 } & Total & 42017 & 100,0 \\
\hline \multirow{3}{*}{ Total } & No & 37935 & 82,8 \\
\cline { 2 - 4 } & Yes & 7869 & 17,2 \\
\cline { 2 - 4 } & Total & 45804 & 100,0 \\
\cline { 2 - 4 } & No & 156096 & 76,7 \\
\cline { 2 - 4 } & Yes & 47504 & 23,3 \\
\cline { 2 - 4 } & Total & 203600 & 100,0 \\
\hline
\end{tabular}

To identify relevant predictors and create financial distress prediction model, Multidimensional Discrimination Analysis was used, which is probably the most frequently used algorithm. Using stepwise discrimination analysis we find relevant predictors of financial distress, with only those predictors being included in the model that possess a sufficient discriminating power. The choice of relevant predictors can also be done on the basis of the test of equality of means between groups of companies that are in financial distress and that are not, but the stepwise method, besides selecting variables, also solves the problem of multi-collinearity.

The main result of this analysis is Fisher canonical discriminant function. It is a linear function of the relevant predictors that separates companies into group of companies in financial distress or healthy companies. For classification of company into one of these two groups, using this discriminant function we can calculate discriminant score. We compare this score with the weighted averages of centroids (average scores in the groups of companies). If we use a constant in discriminant function, it is enough to compare the discriminant score value to zero. Analogously, we could decide on the company's engagement on the basis of the value of Fisher's linear discriminant functions.

If we want to assess the overall quality of the model, we will assess the statistical significance of canonical discriminant function. The contribution of individual predictors to explaining the overall variability can be judged by standardized coefficients of discriminant function and their statistical significance. The classification ability of the obtained model is evaluated by the classification table. This table contains data of the percentages of mistakenly and correctly classified objects in each group. If the model is validated on the sample it was designed for, the classification ability is slightly overvalued. It is appropriate to divide the data into the training sample, used for the model creation and the testing sample, where we verify the classification ability of the model. The size of a training sample is commonly $80 \%$, and $20 \%$ for testing sample. 


\section{RESEARCH RESULTS}

As already mentioned, we use the stepwise Multidimensional Discriminant Analysis to create a prediction model. First, we look at the results of One-way ANOVA to identify predictors that differentiate companies into a group of companies in financial distress and healthy companies. Table 4 shows these results. We can exclude variables X16, X18, X21 and X24 from the next analysis because we cannot claim that their mean values for the two groups of companies are significantly different.

Table 4: Tests of Equality of Group Means

\begin{tabular}{|c|c|c|c|c|c|}
\hline Predictor & Wilks' Lambda & $\boldsymbol{F}$ & $d f 1$ & $d f 2$ & Sig. \\
\hline X01 & ,999 & 60,619 & 1 & 81705 & ,000 \\
\hline $\mathrm{X} 02$ & ,998 & 202,352 & 1 & 81705 &, 000 \\
\hline X04 & ,999 & 51,565 & 1 & 81705 &, 000 \\
\hline X07 & ,999 & 117,866 & 1 & 81705 &, 000 \\
\hline X08 & ,997 & 206,373 & 1 & 81705 &, 000 \\
\hline X09 & ,995 & 372,558 & 1 & 81705 &, 000 \\
\hline $\mathrm{X} 10$ & ,968 & 2693,394 & 1 & 81705 &, 000 \\
\hline $\mathrm{X} 11$ & 1,000 & 28,749 & 1 & 81705 &, 000 \\
\hline $\mathrm{X} 12$ & 1,000 & 11,874 & 1 & 81705 &, 001 \\
\hline $\mathrm{X} 15$ & ,968 & 2671,314 & 1 & 81705 &, 000 \\
\hline $\mathrm{X} 16$ & 1,000 &, 107 & 1 & 81705 &, 744 \\
\hline $\mathrm{X} 18$ & 1,000 &, 042 & 1 & 81705 &, 838 \\
\hline $\mathrm{X} 20$ & 1,000 & 27,066 & 1 & 81705 &, 000 \\
\hline $\mathrm{X} 21$ & 1,000 & 2,119 & 1 & 81705 &, 145 \\
\hline $\mathrm{X} 22$ & ,999 & 87,517 & 1 & 81705 &, 000 \\
\hline $\mathrm{X} 24$ & 1,000 &, 146 & 1 & 81705 &, 702 \\
\hline $\mathrm{X} 25$ & ,998 & 202,355 & 1 & 81705 &, 000 \\
\hline $\mathrm{X} 26$ & 998 & 161,802 & 1 & 81705 &, 000 \\
\hline $\mathrm{X} 27$ & ,995 & 375,779 & 1 & 81705 &, 000 \\
\hline $\mathrm{X} 28$ & ,996 & 317,439 & 1 & 81705 &, 000 \\
\hline X30 & 1,000 & 4,746 & 1 & 81705 &, 029 \\
\hline $\mathrm{X} 35$ & ,993 & 574,576 & 1 & 81705 &, 000 \\
\hline X36 & 1,000 & 13,947 & 1 & 81705 &, 000 \\
\hline X37 & 1,000 & 8,566 & 1 & 81705 &, 003 \\
\hline Country=Croatia & ,999 & 87,811 & 1 & 81705 &, 000 \\
\hline Country=Macedonia & 1,000 & 36,123 & 1 & 81705 &, 000 \\
\hline Country=Montenegro & 1,000 & 21,029 & 1 & 81705 &, 000 \\
\hline Country $=$ Serbia & ,999 & 68,605 & 1 & 81705 &, 000 \\
\hline Country=Slovenia & 1,000 & 13,803 & 1 & 81705 &, 000 \\
\hline Size $=$ Small & ,997 & 281,895 & 1 & 81705 &, 000 \\
\hline Size $=$ Medium & 997 & 237,597 & 1 & 81705 &, 000 \\
\hline Size $=$ Large & 1,000 & 27,225 & 1 & 81705 &, 000 \\
\hline
\end{tabular}

The canonical correlation of discriminant function is significant, but is not very high (only 0,224 ). 
Table 5: Canonical correlation

\begin{tabular}{|c|c|c|c|c|}
\hline Function & Eigenvalue & \% of Variance & Cumulative \% & $\begin{array}{c}\text { Canonical } \\
\text { Correlation }\end{array}$ \\
\hline 1 &, 053 & 100,0 & 100,0 &, 224 \\
\hline $\begin{array}{c}\text { Test of } \\
\text { Function(s) }\end{array}$ & Wilks' Lambda & Chi-square & $d f$ & Sig. \\
\hline 1 &, 950 & 4218,298 & 17 &, 000 \\
\hline
\end{tabular}

The stepwise method included variables to the model one by one. Table 5 shows final list of relevant predictors in our model. Moreover, Table 6 describes the discrimination ability of individual variables. Variables X10 and X15 have the greatest discrimination ability.

Table 6: Standardized Canonical Discriminant Function Coefficients

\begin{tabular}{|l|r|}
\hline Variable & Coefficient \\
\hline X01 &, 082 \\
\hline X02 &, 242 \\
\hline X04 &,- 095 \\
\hline X09 &,- 205 \\
\hline X10 &, 525 \\
\hline X11 &,- 148 \\
\hline X12 &, 104 \\
\hline X15 &, 517 \\
\hline X20 &,- 062 \\
\hline X22 &,- 051 \\
\hline X27 &, 362 \\
\hline X28 &,- 373 \\
\hline X35 &,- 206 \\
\hline Country=Montenegro &, 040 \\
\hline Country=Serbia &,- 164 \\
\hline Country=Slovenia &,- 062 \\
\hline Size=Small &, 237 \\
\hline
\end{tabular}

By using unstandardized canonical discriminant function coefficients (in Table 6); we can calculate a discriminant score for every company that allows to include a company into the group of companies in financial distress or healthy companies.

Table 7: Canonical Discriminant Function Coefficients

\begin{tabular}{|l|r|}
\hline Predictor & Coefficient \\
\hline X01 &, 025 \\
\hline X02 &, 037 \\
\hline X04 &,- 016 \\
\hline X09 & $-1,111$ \\
\hline X10 & 3,861 \\
\hline X11 &,- 511 \\
\hline X12 &, 527 \\
\hline X20 &,- 015 \\
\hline X21 & $-1,928$ \\
\hline X22 &,- 016 \\
\hline X27 & 2,077 \\
\hline
\end{tabular}




\begin{tabular}{|l|r|}
\hline X28 &,- 467 \\
\hline X35 & $-1,290$ \\
\hline Country=Montenegro &, 226 \\
\hline Country=Serbia &,- 371 \\
\hline Country=Slovenia &,- 135 \\
\hline Size=Small &, 567 \\
\hline (Constant) & $-1,977$ \\
\hline
\end{tabular}

Analogously, we could decide on the company's inclusion based on the values of Fisher's Linear Discriminant Functions. For every company, we calculate the value of these discriminant functions. The greater value identifies inclusion to one of the companies groups.

Table 8: Classification Function Coefficients

\begin{tabular}{|l|r|r|}
\hline \multirow{2}{*}{ Predictor } & \multicolumn{2}{|c|}{ Distress } \\
\cline { 2 - 3 } & $\mathbf{N o}$ & Yes \\
\hline X01 &, 053 &, 084 \\
\hline X02 &, 187 &, 233 \\
\hline X04 &,- 004 &,- 024 \\
\hline X09 &, 035 & $-1,360$ \\
\hline X10 & 9,249 & 14,096 \\
\hline X11 & 8,012 & 7,370 \\
\hline X12 & 1,465 & 2,127 \\
\hline X20 &,- 003 &,- 021 \\
\hline X21 & 6,313 & 3,893 \\
\hline X22 &,- 082 &,- 102 \\
\hline X27 & 5,385 & 7,993 \\
\hline X28 &,- 725 & $-1,312$ \\
\hline X35 & 1,736 &, 116 \\
\hline Country=Montenegro & 3,393 & 3,676 \\
\hline Country=Serbia & 3,490 & 3,025 \\
\hline Country=Slovenia & 3,542 & 3,373 \\
\hline Size=Small & 3,992 & 4,704 \\
\hline (Constant) & $-9,470$ & $-12,685$ \\
\hline
\end{tabular}

For practical use of the model it is necessary that the model has sufficient discrimination ability. We evaluate this ability on the basis of a classification table. Based on the Table 8, it is clear that the model has a high ability to identify company financial distress $(93,5 \%$ for the training sample and $90,9 \%$ for the testing sample). The prediction model has relatively high overall discrimination ability. This is because $75,6 \%$ of companies in the testing sample were correctly classified. This prediction ability is $76,0 \%$ for the training sample cases.

Table 9: Classification Results

\begin{tabular}{|c|c|c|c|c|c|}
\hline \multirow[b]{2}{*}{ Sample } & & \multirow[b]{2}{*}{ Distress } & \multicolumn{2}{|c|}{ Predicted Group Membership } & \multirow[b]{2}{*}{ Total } \\
\hline & & & No & Yes & \\
\hline \multirow{4}{*}{$\begin{array}{l}\text { Training } \\
\text { Sample }\end{array}$} & \multirow{2}{*}{ Count } & No & 88259 & 36577 & 124836 \\
\hline & & Yes & 2473 & 35571 & 38044 \\
\hline & \multirow{2}{*}{$\%$} & No & 70,7 & 29,3 & 100,0 \\
\hline & & Yes & 6,5 & 93,5 & 100,0 \\
\hline \multirow{2}{*}{$\begin{array}{l}\text { Testing } \\
\text { Sample }\end{array}$} & \multirow{2}{*}{ Count } & No & 22127 & 9082 & 31209 \\
\hline & & Yes & 866 & 8645 & 9511 \\
\hline
\end{tabular}




\begin{tabular}{|l|l|l|r|r|r|}
\hline \multirow{2}{*}{$\%$} & No & 70,9 & 29,1 & 100,0 \\
\cline { 2 - 5 } & Yes & 9,1 & 90,9 & 100,0 \\
\hline
\end{tabular}

\section{CONCLUSION REMARKS}

We have designed a prediction model for companies from Croatia, Macedonia, Montenegro, Serbia and Slovenia predicting the risk of financial difficulties one year in advance. Multidimensional Discriminant Analysis was used for its creation. We use data calculated form real financial statements of more than 200,000 companies obtained from database Amadeus - A database of comparable financial information for public and private companies across Europe. From the original 32 predictors ( 24 financial indicators and 8 dummy variables), 17 predictors remained in the model. These predictors are not burdened by multi-collinearity, and provide the best identification of financial distress of companies.

Using canonical discriminant function from our model one can calculate discriminant score of a company and based on this score, it is possible to predict the financial distress of this company. Overall prediction ability of the model is relatively high (about $76 \%$ ). But financial distress prediction ability is more than $90 \%$. Therefore, we can consider the model to be relatively reliable for prediction of financial distress one year in advance. Although the model was created for companies in selected Balkan countries, it may be applicable also to other emerging market countries.

\section{ACKNOWLEDGEMENT}

This research was financially supported by the Slovak Research and Development Agency - Grant NO. APVV-14-0841: Comprehensive Prediction Model of the Financial Health of Slovak Companies.

\section{REFERENCES}

Altman, E. I. (1968). Financial Ratios, Discriminant Analysis and the Prediction of Corporate Bankruptcy. The Journal of Finance, 23(4), 589-609. ISSN 1540-6261. doi: 10.1111/j.15406261.1968.tb00843.x

Altman, E. I., Iwanicz-Drozdowska, M., Laitinen, E. K., Suvas, A. (2016). Financial Distress Prediction in an International Context: A Review and Empirical Analysis of Altman's ZScore Model. Journal of International Financial Management \& Accounting, 28(2), 131171. doi: 10.1111/jifm.12053

Bellovary, J. L., Giacomino, D., Akers, M. D. (2007). A Review of Bankruptcy Prediction Studies: 1930 to Present. Journal of Financial Education, 33, 1-43.

Bonca, P. D., Ponikvar, N., Pusnik, K., Tajnikar, M. (2015). The Role of Management Decision in Explaining Firm Market Exit. E \& M Ekonomie a Management, 18(2), 103-116. doi: 10.15240/tul/001/2015-2-008

Chung, K. Ch., Tan, S. S., Holdsworth, D. K. (2008). Insolvency Prediction Model Using Multivariate Discriminant Analysis and Artificial Neural Network for the Finance Industry in New Zealand. International Journal of Business and Management, 39(1), 19-28.

Jovanovic, D., Todorovic, M., Grbic, M. (2017). Financial Indicators as Predictors of Illiquidity. Romanian Journal of Economic Forecasting, 20(1), 128-149.

Kliestikova, J., Misankova, M., Kliestik, T. (2017). Bankruptcy in Slovakia: international comparison of the creditor's position. Oeconomia Copernicana, 8(2), 221-237. doi: 10.24136/oc.v8i2.14 
Kundid, A., Ercegovac, R. (2011). Credit rationing in financial distress: Croatia SMEs finance approach. International Journal of Law and Management, 53(1), 62-84. doi: $10.1108 / 17542431111111890$

Li, J., Ragozar, R. (2012). Application of the Z -Score Model with Consideration of Total Assets Volatility in Predicting Corporate Financial Failures from 2000-2010. Journal of Accounting and Finance, 12(2), 11-19.

Obradovic, D. B., Jaksic, D., Rupic, I. B., Andric, M. (2018). Insolvency prediction model of the company: the case of the Republic of Serbia. Economic Research-Ekonomska Istrazivanja, 31(1), 139-157. doi: 10.1080/1331677X.2017.1421990

Ohlson, J. A. (1980). Financial Ratios and the Probabilistic Prediction of Bankruptcy. Journal of Accounting Research, 18(1), 109-131. ISSN 1475-679X. doi: 10.2307/2490395

Pervan, I., Pavic, P., Pervan, M. (2014). Firm Financial Distress Prediction with Statistical Methods: Prediction Accuracy Improvements Based on the Financial Data Restatements. Proceedings of 8th International Days of Statistics and Economics, Sep 11-13, 2014, Prague, Czech Republic, pp. 1134-1144.

Sarlija, N., Jeger, M. (2011). Comparing Financial Distress prediction Models Before and During Recession. Croatian Operational Research Review-Book Series, 2, 133-142.

Shams, M. F., Sheikhi, M., Sheikhi, Z. (2011). Financial distress prediction: Comparisons of logit models using receiver operating characteristic (ROC) curve analysis. African Journal of Business Management, 5(30), 12164-12173. doi: 10.5897/AJBM11.1969

Siekelova, A., Kliestik, T., Svabova, L., Androniceanu, A., Schonfeld, J. (2017). Receivables Management: The Importance of Financial Indicators in Assessing the Creditworthiness. Political Journal of Management Studies, 15(2), 217-228. doi: 10.17512/pjms.2017.15.2.20

Simic, D., Kovacevic, I., Simic, S. (2012). Insolvency prediction for assessing corporate financial health. Logic Journal of the IGPL, 20(3), 536-549. doi: 10.1093/jigpal/jzr009

Sun, J., Li, H. (2012). Financial distress prediction using support vector machines: ensemble vs. individual. Applied Soft Computing, 12(8), 2254-2265. doi: 10.1016/j.asoc.2012.03.028

Zidek, L. (2016). Economic Transformation in Slovenia: From a Model Example to the Default Edge. Review of Economic Perspectives, 16(3), 159-186. doi: 10.1515/revecp-2016-0011

Zikovic, I. T. (2018). Challenges in Predicting Financial Distress in Emerging Economies: The Case of Croatia. Eastern European Economics, 56(1), 1-27. doi: 10.1080/00128775.2017.1387059 